WIDER Working Paper 2019/53

Linkages and spillover effects of South African foreign direct investment in Botswana and Kenya

Felix Adamu Nandonde, ${ }^{1}$ Richard Adu-Gyamfi, ${ }^{2}$ TinayeSonto Mmusi, ${ }^{3}$ Herbert Wamalwa, ${ }^{4}$ Simplice A. Asongu, ${ }^{5}$ Johannes Pieter Opperman, ${ }^{6}$ and Jeremiah R. Makindara ${ }^{7}$

July 2019 
Abstract: In recent decades, the impact of South African foreign direct investment in Africa has been captured by research and policy. This paper investigates linkages and spillover effects of South African foreign direct investment in Botswana and Kenya. The study uses primary data to investigate qualitative implications. The findings reveal that South African firms operate in sectors including retail, food-processing, and information and communication technology. Linkages forged in these sectors include supply, employee, joint venture, service, and institutional nexuses. Supply and service linkages create observable spillovers which point to the fact that younger local firms tend to benefit from South African firms in terms of technology transfer and training opportunities. Host country policymakers are therefore encouraged to provide favourable incentives for foreign direct investment to promote entrepreneurship. Other policy implications are also discussed.

Keywords: Botswana, foreign direct investment, Kenya, linkages, South Africa, spillover effects JEL classification: E23, F21 F30, L96, L98, O55

Acknowledgements: We are indebted to John Page for his constructive comments, which helped us to improve the quality of this paper.

1Sokoine University of Agriculture, Morogoro, Tanzania, corresponding author: nandonde@sua.ac.tz 2International Trade Centre, Geneva, Switzerland. ${ }^{3}$ Gaborone University College of Law and Professional Studies, Botswana/Consortium of Leadership and Gender Experts (PTY) Ltd, Gaborone, Botswana. ${ }^{4}$ University of Nairobi, Kenya. ${ }^{5}$ African Governance and Development Institute, Yaoundé, Cameroon. ${ }^{6}$ University of Stellenbosch, South Africa. ${ }^{7}$ Sokoine University of Agriculture, Morogoro, Tanzania.

This study has been prepared within the UNU-WIDER project on 'Southern Africa-Towards Inclusive Economic Development (SA-TIED)'.

Copyright (C) UNU-WIDER 2019

Information and requests: publications@wider.unu.edu

ISSN 1798-7237 ISBN 978-92-9256-687-6

https://doi.org/10.35188/UNU-WIDER/2019/687-6

Typescript prepared by Merl Storr.

The United Nations University World Institute for Development Economics Research provides economic analysis and policy advice with the aim of promoting sustainable and equitable development. The Institute began operations in 1985 in Helsinki, Finland, as the first research and training centre of the United Nations University. Today it is a unique blend of think tank, research institute, and UN agency — providing a range of services from policy advice to governments as well as freely available original research.

The Institute is funded through income from an endowment fund with additional contributions to its work programme from Finland, Sweden, and the United Kingdom as well as earmarked contributions for specific projects from a variety of donors.

Katajanokanlaituri 6 B, 00160 Helsinki, Finland

The views expressed in this paper are those of the author(s), and do not necessarily reflect the views of the Institute or the United Nations University, nor the programme/project donors. 
This paper investigates linkages and spillover effects of South African foreign direct investment (FDI) in Botswana and Kenya. Since the end of apartheid in South Africa, many South African firms in retail, banking, agro-processing, and others sectors have expanded to other African countries. This has obviously influenced employment trends in the host countries, and offers opportunities for local firms to improve their practices and performance (Adu-Gyamfi 2017). However, linking host country firms to South African firms has remained a challenge, due to the former's low levels of capability in productivity or quality to engage with highly capable South African firms (Sutton 2012). In some cases in retail, South African firms return to procure products from their home market to serve the host country market. Research by Nandonde (2016) revealed that Shoprite, a South African retail giant, imported about 80 per cent of its stock of food items from South Africa when it operated in Tanzania. This somewhat enclave behaviour prompted the Tanzanian government to introduce a policy demanding that at least 50 per cent of processed goods be procured locally. Policy has thus become a useful approach to intensify the interactions between South African and local firms. In Kenya, for instance, policy regulations allow partnerships, illustrated by the alliance between South Africa's Nedbank and Ecobank Kenya (Muchira 2017). Such interactions pave the way to deepen linkages between South African firms and local firms. Consequently, the linkages currently being forged by South African firms, and the spillovers generated by South African FDI in host countries, should be further investigated.

Previous literature on FDI in Africa can be categorized into two strands. On the one hand, studies on regional and national economic growth from South African FDI (including existent gaps) focus inter alia on FDI and convergence in regional wealth (Dunne and Masiyandima 2017), the relevance of influences at the global level on the portfolio of African economic sectors (Boamah 2017), and nexuses between bonds, equity, institutional debt, and economic development (Fanta and Makina 2017). Others focus on output estimation gaps in the light of potential economic prosperity (Fedderke and Mengisteab 2017). On the other hand, extant studies on productivity are concerned inter alia with linkages between total factor productivity (TFP), output per worker, remittances, and technological gain (Ssozi and Asongu 2016a, 2016b), the role of value chains in the relevance of FDI for driving economic growth and productivity (Meniago and Asongu 2019), gender disparities and labour supply (Elu and Price 2017), schooling features and the intensity of child labour (Ahouakan and Diene 2017), and linkages between manufacturing and exporting (Cisse 2017). Others examine the nexuses between manufacturing corporations and TFP within the framework of variations in the rate of productivity across manufacturing industry sectors (Kreuser and Newman 2018) and the relevance of information technology for TFP catch-up (Maryam and Jehan 2018).

Departing from contemporary FDI and productivity studies and scholarship on Africa, this paper focuses on FDI linkages and spillovers by examining country-specific cases, using primary data to investigate qualitative implications. In line with to the aims of previous studies, this paper helps to enrich the South African FDI discourse in Africa by providing evidence from Botswana and Kenya. Specifically, the following research questions are pursued:

1. What are the linkages forged by South African firms in Botswana and Kenya?

2. What spillover effects emerge from linkages between South African firms and local firms in the host countries?

We contend that knowledge of South African FDI practices in host countries should inform policy and institutional reforms to enhance linkages and spillover effects. The rest of the paper is 
structured as follows. Section 2 briefly introduces the theory of FDI and discusses the nature of South African FDI. The section further discusses the theory of linkages and spillovers, and outlines the operational framework that guided the empirical study. Section 3 provides the research methodology. Section 4 elaborates the empirical findings, and section 5 concludes with implications and future research directions.

\section{Theory of FDI}

The theory of FDI relates to the movement of capital across national boundaries. Seminal works on FDI by Vernon (1966) and Hymer (1976) illustrate the central role played by multinational firms in cross-border expansion. In effect, firms are motivated to seek markets, efficiencies, resources, and strategic assets (Dunning 1993; Meyer 2015). Market-seeking firms engage in foreign operations to increase or sustain their market share by avoiding barriers that hinder their performance in home markets (Cui et al. 2014; Kuada 2005; Meyer 2015). Efficiency-seeking firms have the objective of targeting advantages, such as low costs and availability of labour in host markets (Cui et al. 2014; Kuada 2005). Natural resource-seeking firms aim to use host country natural resources to enhance in-house production, or sell acquired resources to other firms in host markets (Cui et al. 2014; Kuada 2005; Ramasamy et al. 2012). Lastly, strategic asset-seeking firms enter host markets to build their assets rather than exploit existing assets (Meyer 2015). This brief exposition of the theoretical underpinnings of FDI offers a basis to relate to the intentions of South African firms in host countries.

\subsection{South African FDI}

South African FDI spans both African and non-African economies. Table 1 shows that South African firms are among the top 100 multinational enterprises from developing and transition economies (UNCTAD 2018). Indeed, footprints of South African firms outside Africa are traceable in the healthcare, industrial, telecommunication, technology, financial, consumer goods, and basic materials sectors (Konfidants 2017). Previously, many South African firms found it difficult to expand beyond the home market, largely due to restrictions placed on the apartheid regime. Nevertheless, corporations used these restrictions to consolidate their strength at home before expanding into regional and global markets (Konfidants 2017) after the end of the apartheid regime. It is not surprising that there are many South African investments dotted across the world. South African firms generate 17 per cent of sales outside Africa (Labour Research Service 2017).

South African FDI across the African continent increased by over 200 per cent from US $\$ 74$ million in 2016 to US $\$ 151$ million in 2017 (UNCTAD 2018). This illustrates a huge, bold entrepreneurial drive in international opportunity identification (Cuero Acosta et al. 2017). In 2016, South African FDI was the highest in Africa in terms of the number of projects (Table 2). Although this dropped to 96 projects in 2017, South Africa still maintained a clear lead among the top five FDI in Africa by project. Beyond projects, the number of South African firms operating across Africa is huge anecdotally, but a recent sample study reveals that there are over 250 South African multinational operations on the continent, including in South Africa (Labour Research Service 2017). Driven by resource- and market-seeking motives, they are found in banking and financial services, construction, diversified holdings, education, bus training and employment, food and beverages, health, hospitality, industry, mining, paper and packaging, retail, technology and communications, and manufacturing (Labour Research Service 2017; Muchira 2017). South African firms generate 70 per cent of sales from their home country, but also generate 13 per cent and 17 per cent of sales from the rest of Africa and the world respectively (Labour Research Service 2017). 
Table 1: Top 100 multinational enterprises from developing and transition economies by home country

\begin{tabular}{|c|c|c|}
\hline Economy & 2011 & 2016 \\
\hline Africa & 9 & 7 \\
\hline South Africa & 8 & 6 \\
\hline Asia & 75 & 77 \\
\hline Hong Kong, China & 20 & 13 \\
\hline China & 12 & 24 \\
\hline Singapore & 9 & 9 \\
\hline Taiwan Province of China & 9 & 6 \\
\hline India & 8 & 6 \\
\hline Malaysia & 6 & 5 \\
\hline Latin America and the Caribbean & 10 & 14 \\
\hline Brazil & 4 & 5 \\
\hline Mexico & 4 & 7 \\
\hline Russian Federation & 6 & 2 \\
\hline Total & 100 & 100 \\
\hline
\end{tabular}

Source: UNCTAD (2018).

Table 2: Top five FDI in Africa by project in numbers

\begin{tabular}{lrr}
\hline Country & 2016 & 2017 \\
South Africa & 105 & 96 \\
Morocco & 80 & 88 \\
Egypt & 69 & 67 \\
Nigeria & 49 & 35 \\
Kenya & 38 & 42 \\
\hline
\end{tabular}

Source: authors' compilation based on data from fDi Intelligence $(2017,2018)$.

Table 3: South African FDI in Botswana and Kenya

\begin{tabular}{lrr}
\hline Sector & Botswana & Kenya \\
Banking and financial services & 8 & 7 \\
Construction & 7 & 2 \\
Diversified holdings & 2 & 2 \\
Education, bus training and employment & 1 & - \\
Food and beverage & 5 & 2 \\
Health & 2 & 3 \\
Hospitality & 2 & 2 \\
Industrial & 4 & 1 \\
Mining & 1 & - \\
Paper and packaging & 1 & 1 \\
Retail & 2 \\
Technology and communications & 9 & 4 \\
Transport & 1 & - \\
Total & 3 & 2 \\
\hline
\end{tabular}

Source: authors' compilation based on data from Labour Research Service (2019).

Studies show that South African firms in Botswana and Kenya are dominant in retail as well as in the banking and financial sector. Table 3 presents the various sectors where South African firms are engaged in Botswana and Kenya. Competitors such as Shoprite, Massmart, Pick n Pay, Woolworths, Foschini, Truworths, Cashbuild, Mr Price Group, and Spar dominate the retail sector. In banking and finance, sector giants include the Standard Bank Group, Liberty Holdings, FirstRand Bank, African Bank Investments, Sanlam, Absa, RMB Holdings, and Barclays Africa 
Group (Labour Research Service 2019). There are also other strong banking multinationals such as Nedbank and Old Mutual present in Kenya (Adeyele et al. 2018). Banks provide commercial, retail, private banking, asset management, credit card, mortgage, and other services in host economies.

In comparison, there is more South African FDI in the food and beverage sector in Botswana than in Kenya. Pioneer Foods, Tongaat Hulett, Clover Industries, and RCL Foods operate in Botswana, while Tiger Brands operates in Kenya. Distell operates in both countries. Country Bird Holdings has also penetrated the market to serve chicken products for consumers. Although it is not captured by the Labour Research Service, South African FDI in Kenya can also be found in telecommunications. In the information and communication technology (ICT) sector, South African investors such as Naspers, the MTN Group, and Intact Software Ltd have found their way into the Kenyan market. Telkom South Africa has gained a strong local presence through local firm acquisition strategies (Irungu 2010).

South African firms in Botswana and Kenya are generally market-seeking, given the profits accrued (shown in Table 4). Despite fluctuations in yearly average profit margins, South African firms accrue positive figures. Thus, profit margins give the impression that both economies are fertile ground for South African firms to thrive. As shown in Table 4, South African firms have been operating for over a decade in Botswana and Kenya. The length of operations and the increase over time in the number of South African firms in both countries illustrate the extent to which South African FDI has grown in host markets. Nevertheless, it is unclear whether South African firms conduct business at arms' length or go further to deepen relationships with host country markets. One way to find out is to investigate linkages and spillover effects of South African FDI in Botswana and Kenya. This should inform policy directives that will foster linkages to generate favourable spillovers and mitigate undesired ones.

Table 4: Company performance of South African multinational corporations in Botswana and Kenya

\begin{tabular}{|c|c|c|c|c|c|c|}
\hline \multirow[b]{2}{*}{ Year } & \multicolumn{3}{|c|}{ Botswana } & \multicolumn{3}{|c|}{ Kenya } \\
\hline & $\begin{array}{l}\text { No. of } \\
\text { companies }\end{array}$ & $\begin{array}{l}\text { Average } \\
\text { revenue } \\
\text { in US\$ million }\end{array}$ & $\begin{array}{l}\text { Average profit } \\
\text { after tax in } \\
\text { US } \$ \text { million }\end{array}$ & $\begin{array}{l}\text { No. of } \\
\text { companies }\end{array}$ & $\begin{array}{l}\text { Average } \\
\text { revenue } \\
\text { in US\$ million }\end{array}$ & $\begin{array}{l}\text { Average profit } \\
\text { after tax in } \\
\text { US } \$ \text { million }\end{array}$ \\
\hline 2007 & 8 & 8243.22 & 1782.85 & 3 & 11612.36 & 1462.02 \\
\hline 2008 & 36 & 4663.87 & 616.82 & 18 & 4415.46 & 464.41 \\
\hline 2009 & 40 & 4851.34 & 417.83 & 21 & 5189.01 & 409.79 \\
\hline 2010 & 44 & 5239.02 & 570.33 & 25 & 4906.35 & 437.58 \\
\hline 2011 & 47 & 7384.83 & 712.36 & 27 & 5966.33 & 460.31 \\
\hline 2012 & 49 & 7430.38 & 536.29 & 29 & 6209.28 & 554.24 \\
\hline 2013 & 47 & 5499.21 & 471.11 & 27 & 5755.00 & 585.77 \\
\hline 2014 & 46 & 5181.79 & 444.72 & 27 & 5336.86 & 575.41 \\
\hline 2015 & 46 & 4516.03 & 293.49 & 27 & 4671.53 & 541.76 \\
\hline 2016 & 46 & 4066.35 & 352.46 & 27 & 4302.41 & 499.92 \\
\hline 2017 & 44 & 3761.34 & 342.99 & 25 & 3360.07 & 379.68 \\
\hline
\end{tabular}

Source: authors' compilation based on data from Labour Research Service (2019). 


\subsection{Linkages}

Linkage is defined as the 'organisational modalities of interactions' between firms (Rugraff and Hansen 2011: 16). Altenburg (2000) and Santangelo (2009), however, define linkages to include non-business entities such as universities and government institutions. Consolidating these definitions, Adu-Gyamfi (2017) refers to linkages as interactions between business and nonbusiness entities. This inclusive definition is appealing, and is therefore used as the guiding definition of linkages in this paper. The concept of linkages is useful to understand value chain governance. The value chain describes the full range of activities conducted to bring a product into being for use and beyond (Gereffi and Fernandez-Stark 2016). Such activities include research and development, design, production, marketing, distribution, and support to the end consumer (Gereffi and Fernandez-Stark 2016). Value chain activities have global (Gereffi 1999; Henderson et al. 2002), international (ITC 2017), regional (Tamara 2018), and national dimensions. Multinational lead firms drive global and international value chains, where they exert a lot of influence on upstream and downstream activities related to product or service requirements regarding standards, design, and quality. Local firms willing to connect to global value chains should be able to fulfil these requirements, and by doing so are granted access to a rich pool of knowledge. In national value chains, clusters also offer wide linkage opportunities. Clusters are geographical concentrations of enterprises that co-locate to benefit from customers, traders, workers with related skills, suppliers of inputs, service providers, and other enterprises keen to exploit new market opportunities (McCormick 1999; Porter 1990; Schmitz 1992). Different actors in both value chains and clusters augur well for linkage formation.

The literature on linkages shows two main categories: vertical and horizontal. Vertical linkages are subdivided into backward (upstream) and forward (downstream) linkages. Vertical backward linkages are forged based on the need to provide supply to initiate production. Some empirical evidence shows that backward linkages generally occur between foreign fruit-processing enterprises and mango and pineapple suppliers in Ghana (Adu-Gyamfi 2017). Others occur between the automobile giant $\mathrm{AB}$ Volvo and component suppliers in India, Brazil, China, and Mexico (Ivarsson and Alvstam 2005). Furthermore, evidence of backward linkages is found in Smarzynska Javorcik's (2004) work on foreign affiliates and local suppliers in upstream sectors in Lithuania. More evidence is underscored by the presence of backward linkages in Northern Ireland, particularly in supplier relationships between multinationals and local suppliers (Crone and Roper 2001). Vertical forward linkages are forged based on the need to provide finished goods or services to the consumer market. Empirical evidence has revealed forward linkages between foreign firms and the development of local distributors and sales organizations (Blomström and Kokko 1998; Reuber et al. 1973). A study by Miozzo and Grimshaw (2008) also demonstrated forward linkages between multinational service firms and their client firms in Argentina and Brazil.

Horizontal linkages demonstrate interactions between foreign and local firms who act as partners or competitors. Empirical evidence shows strong relationships between foreign subsidiaries and alliance partners from the host economy in New Zealand (Scott-Kennel and Enderwick 2004). This is due to the mutual but unequal transfer of product (service) technology, research and development, management practices, and marketing and distribution system resources from each side of the alliance (Scott-Kennel and Enderwick 2004). Other empirical work has also revealed horizontal linkages in the form of international joint ventures (Adu-Gyamfi 2017; Liu and Vince 1999; Si and Bruton 2005).

Beyond vertical and horizontal linkages, some authors underscore the usefulness of institutional linkages between firms and institutions such as universities, public research centres, and advocacy groups (e.g., Santangelo 2009). There are also ancillary linkages forged by foreign firms regarding services such as subcontracting and finance (e.g., Chen et al. 2004). Through cohort and funnel 
approaches, Prashantham (2019) also demonstrates new forms of viable collaboration interface between big corporations and start-ups. According to the author, the cohort approach describes start-ups' participation in programmes organized by big corporations where peer-to-peer engagement is a key part. The funnel approach allows big corporations to prescreen start-ups for subsequent engagement. In both the cohort and the funnel approach, corporations are able to tap into valuable new ideas from start-ups, while the latter gain access to the resources and legitimacy provided by corporations. Given the points raised, a broad view of linkages enables us to observe potential spillovers that may or may not ensue between foreign firms and the host country market.

\subsection{Spillovers}

Spillovers are outcomes of linkages forged by the presence of FDI. According to Smarzynska Javorcik (2004), FDI may create vertical or horizontal spillovers. In effect, vertical spillovers are born from vertical linkages. Empirical evidence shows that supply linkages may engender supplier development (Adu-Gyamfi 2017), and labour linkages may create avenues for employee training and technical assistance (Giroud and Scott-Kennel 2009; Kuada 2005; Scott-Kennel and Enderwick 2005). Horizontal spillovers may occur when local firms learn by imitating foreign firms without the latter's conscious effort or prior knowledge (Scott-Kennel and Enderwick 2005). This may augment the capability of a local firm to compete with the foreign firm in the host market. In relation to this, Sutton (2012) underscores that FDI can be a source of local firms' capabilitybuilding in productivity and quality. Similarly, Altenburg (2000) argues that foreign firms have higher managerial and technical capabilities that could be transferred to local firms to enhance their business practices. Thus, capability-building is a combination of tacit knowledge and working practices that can be introduced to local firms (Newman et al. 2016: 111). Through interactions between foreign and local firms, the latter may learn to develop their competitiveness in productivity and quality. Thus, capability-building is a spillover of the initial interaction between foreign and local firms. It may also be manifested in employee training aided by labour linkages (Scott-Kennel and Enderwick 2005) or institutional linkages (Santangelo 2009). In light of the literature, these theoretical and empirical expositions offer a basis from which to observe linkages forged between South African firms and host country firms, as well as the ensuing spillovers.

\subsection{Research operationalization}

Following on from the literature review, linkages and spillover effects of South African FDI on host country firms can be articulated through channels that emphasize the positive effects of FDI on development outcomes in the subregion. First, there is the linkage channel, which allows local firms to tap into the knowledge repository of foreign investors (Adu-Gyamfi 2017) and build capabilities (Sutton 2012). The linkage channel also promotes improved training in management and labour operations (Giroud and Scott-Kennel 2009; Scott-Kennel and Enderwick 2005). In addition, the linkage channel enhances the competitiveness of local firms through improved investments in physical and human capital, more efficiency, and better productivity (Sutton 2012). Second, there is the demonstration channel, where the mere presence of foreign firms stimulates local firms' tendency to imitate foreign corporations in strategies of production as well the distribution of goods and services (Kuada 2005; Scott-Kennel and Enderwick 2005).

We focus on both linkage channels, since policy regulations in the region would like to see an improvement in the capability of local firms through vertical FDI. We demonstrate the presence or absence of vertical backward linkages by using supply as a proxy indicator between South African firms and host country firms. In effect, supply linkages reflect the interaction that captures the inputs provided by host country firms to South African firms. Employee linkages refer to local workers employed by South African firms. The presence of local employees in South African firms is used as a proxy indicator. We expect South African firms to form horizontal linkages with local 
firms, since that allows the former to shorten the period of learning about the host market. The presence of a joint venture is used as a proxy indicator to investigate horizontal linkages. Furthermore, we expect to see ancillary linkages manifested in the provision of services such as transport, Internet provision, and others, given that South African firms are unable to internalize all operations and must therefore obtain such services from the market. Institutional linkages are used to investigate linkages forged between South African firms and local institutions (e.g., universities). Given that South African FDI spans across various sectors, we focus on a heterogeneous group of sectors to capture linkages that may be formed between South African firms and host country firms and the associated spillover effects. These sectors include retail, foodprocessing, financial services, communication technology, and hospitality. All linkages are observed from the perspective of the South African firm.

For spillovers, we expect to see effects manifested mainly by supply and employee linkages, since these are core vertical inputs for South African firms. Thus, we expect spillovers to be seen through the following proxy indicators: training, financial support, inputs (tangible and intangible), and advice and recommendations. These are supposed to assist us in understanding the improvement situations of local firms. All spillovers are observed from the perspective of the local firm.

Table 5 outlines the research dimensions and indicators. General firm characteristics include firm size, length of operation, number of employees, ownership structure, and company products or services. To ensure the reliability of data which demonstrates the presence of linkages and spillovers, it was a criterion for inclusion that the South African firm had been in business for at least two years. An existing local firm qualified for inclusion if it was identified through a South African firm and had been in operation for at least two years.

Table 5: Research constructs and indicators

\begin{tabular}{lll}
\hline Dimension & Indicators & Targeted respondents \\
\hline Sectors & Retail & South African firms \\
& Food-processing & \\
& Finance & \\
ICT & Hospitality & South African firms \\
Firm characteristics & Firm size & Local firms \\
& Firm product/service & \\
& Length of operation & \\
& No. of employees & \\
& $\bullet \quad$ South African employees & \\
& $\bullet \quad$ Local employees & \\
& $\bullet \quad$ Lale/female employees & South African firms \\
& Ownership structure & \\
Linkages & Supply middle and senior positions & \\
& Employee & \\
Joint venture & Local firms \\
& Service & \\
Institutional & \\
Training & Financial support \\
Inputs (tangible and intangible) & Advice and recommendations & \\
\hline
\end{tabular}

Source: authors' compilation. 


\subsection{Empirical setting}

The countries included in the study were Botswana and Kenya. Botswana is a landlocked country in Southern Africa which shares borders with Namibia, Zambia, Zimbabwe, and South Africa. Evidence shows that the real gross domestic product (GDP) of Botswana grew from 2.4 per cent in 2017 to an estimated 4.2 per cent in 2018 (African Development Bank 2019). This occurred primarily through resumed mining and non-mining activities. Botswana is regarded as one of the most politically and economically stable democracies in sub-Saharan Africa. Kenya borders on Tanzania, Uganda, South Sudan, Ethiopia, Somalia, and the Indian Ocean. Kenya's real GDP increased from 4.9 per cent in 2017 to about 5.9 per cent in 2018 (African Development Bank 2019). This was a result of good weather, a relatively eased political climate, improved business confidence, and strong private consumption. Given these conditions, both Botswana and Kenya are generally good investment locations. The countries were selected for the study to represent an African region that covers two different economic zones serving the Southern African economic subregion: the Southern African Development Community (SADC) and the Common Market for Eastern and Southern Africa (COMESA). Although Kenya is not a member of the SADC, it belongs to COMESA, to which SADC members also belong. Therefore, its trade practices with South African foreign investors offer research lessons not provided by Botswana, which is a member of the SADC. Due to limited resources and unforeseen circumstances, it was difficult to include more SADC countries in our study.

\subsection{Data collection and analysis}

Our research employed a qualitative approach to gain detailed and contextualized results regarding the case studies (Adu-Gyamfi 2017; Steckler et al. 1992). Our sampling technique was the snowballing approach. This approach allows the researcher to gather information by contacting a respondent who then provides leads to further potential respondents for the study (Adu-Gyamfi 2017; Biernacki and Waldorf 1981). We started with key informants to identify South African FDI projects in Botswana and Kenya. This was essential because there was no known list of South African enterprises working in the two countries. Similarly, there were no known lists of local companies working with South African firms. The key informants initially contacted were officials in the South African High Commission's offices in Botswana and Kenya. They provided leads to South African firms on an anecdotal basis. Based on these referrals, South African firms helped us to reach local firms. Consequently, the research relied on primary data obtained through interviews with representatives of South African FDI and local firms. The study was initially designed for the agro-processing sector. However, difficulty in gaining access compelled the researchers to expand and accommodate sectors where other South African FDI was also active. The South African firms interviewed included firms in the food-processing, retail, and ICT sectors.

Table 6: Summary of interviewed firms

\begin{tabular}{lrrr}
\hline Country & South African firms & Local firms & Totals \\
Kenya & 3 & 19 & 22 \\
Botswana & 2 & 2 & 4 \\
Totals & 5 & 21 & 26 \\
\hline
\end{tabular}

Source: authors' compilation.

In Botswana, seven South African firms were invited to participate in an interview; only two agreed to do so. One South African firm assisted us in reaching nine local firms, only one of which agreed to take part in an interview. The second South African firm assisted us in reaching three local 
firms, one of which agreed to take part in an interview. Both the South African firms and the local firms were located in Gaborone, the capital of Botswana.

In Kenya, an initial search yielded 12 South African firms to be interviewed. Of these, eight responded to our invitation, of which only three ultimately agreed to be interviewed. These three firms provided leads to 25 local firms. Of these, 19 were interviewed successfully. Sixteen of these 19 local firms were located in the capital city, Nairobi. Two were in Thika, and one was in Mombasa. All three South African firms were located in Nairobi. A semi-structured questionnaire served as a guide in the interview process. Each interview lasted between 30 minutes and one hour. The interviews were conducted between December 2018 and February 2019. Qualitative narratives were compiled based on the information gathered from the interviews.

\section{Limitations}

The sample size in our research is very small. Three main issues hindered the acquisition of a greater number of respondents. First, there were logistical delays when transferring the funds to support data collection in Botswana and Kenya: the corresponding author had to undergo strict money-laundering checks before the transfer was possible. Second, since there were no readily available databases in the host countries to enable us to locate South African firms, it was quite difficult to locate such firms, or an appropriate focal point to engage with them, in Botswana and Kenya. Third, many of the South African firms that were ultimately contacted declined to participate in the research. For them, it was imperative to receive clearance from their headquarters in South Africa before granting interviews. Many firms were still at the clearance-seeking stage at the end of the data collection period.

\section{$4 \quad$ Research findings}

\subsection{Characteristics of South African firms in Botswana and Kenya}

Of the two South African firms interviewed in Botswana, one (henceforth SA1) is in the retail sector, the other (SA2) in the food sector. SA1 has been operating for more than 20 years; SA2 has been in operation for between six and 10 years. The ownership structure for SA1 is a joint venture with 256 employees. Female employees constitute 49 per cent of total employment. Despite being a South African firm, SA1 has only local employees. SA2 has 55 employees, with 36 per cent female inclusion; all its employees hail from Botswana.

Of the three South African firms interviewed in Kenya, two are in ICT (SA3 and SA4), and the third (SA5) in the retail sector. SA3 generates ICT systems for the Kenyan market. SA4 provides Internet, wide area network, cloud, data, and other services for the Kenyan market. In the retail sector, SA 5 conducts business in general merchandise and fast-moving consumer goods. SA 3 has been conducting business in Kenya for between 11 and 15 years. SA4 has been in operation for between 16 and 20 years. SA5 has been operational for between three and five years. SA3 is a wholly foreign firm in Kenya, with an workforce of 150 workers: 105 male and 45 female. Seven local employees hold senior management positions, and five employees are in middle management positions. These three cases are a mix of young and old South African firms, revealing the dynamic and fashionable nature of South African investment.

Table 7 presents the characteristics of the five South African firms interviewed. 
Table 7: Characteristics of South African firms in Botswana and Kenya

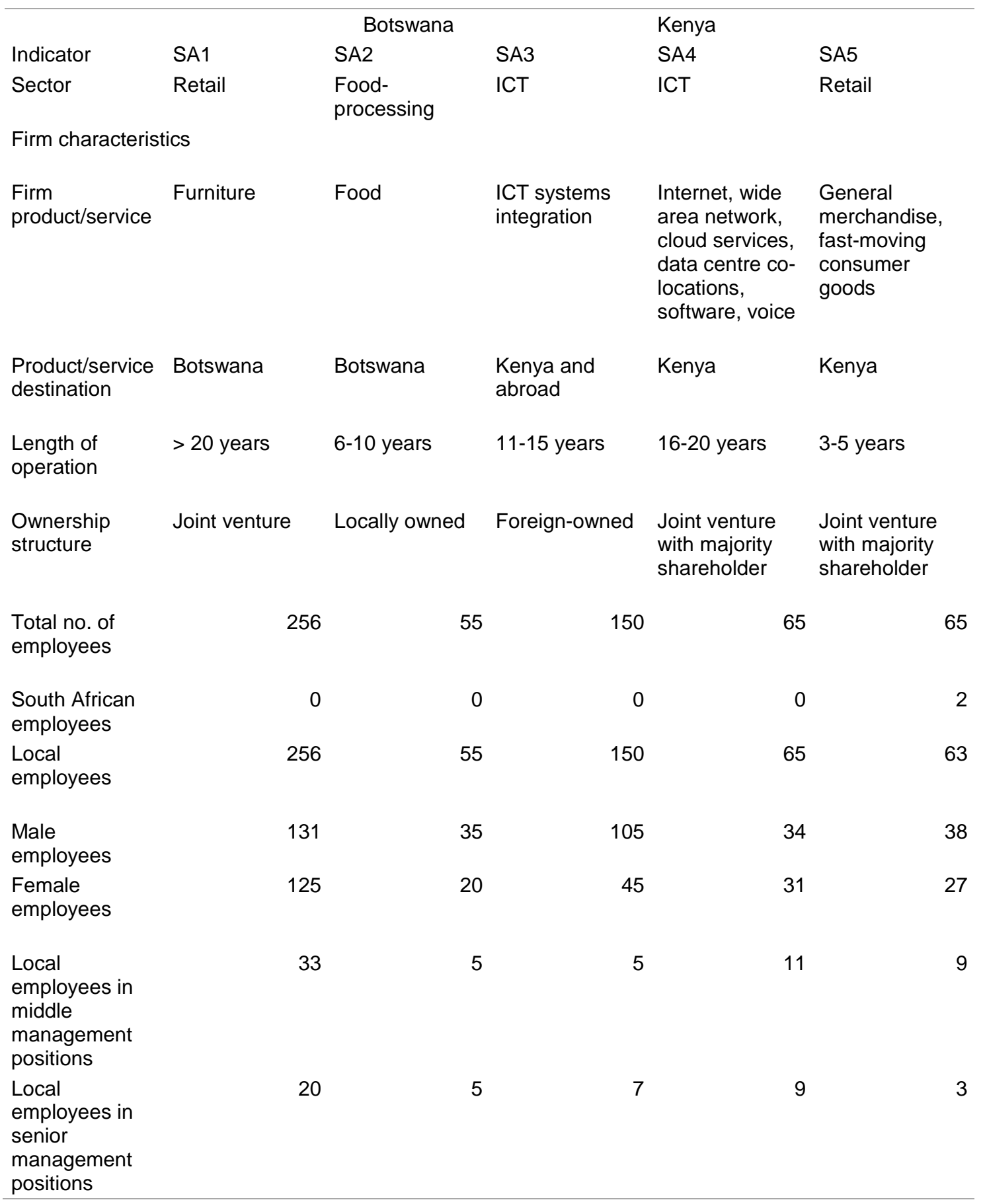

Source: authors' compilation.

\subsection{Linkages forged by South African firms in Botswana and Kenya}

Our findings reveal different types of linkage forged by South African firms in Botswana and Kenya. Table 8 reports the linkages forged by South African firms in host countries. The majority of supply linkages forged by South African firms involve local suppliers. Institutional linkages are minimal but present; they are forged with foreign institutions in the host country. Nevertheless, supply, employee, joint venture, and service linkages are found in all three sectors, i.e. retail, foodprocessing, and ICT. Institutional linkages are forged in the ICT and retail sectors. To judge from the findings, South African firms are spread across different sectors and industries. South African firms supply furniture for interior design, household items, and décor appliances, as well as a 
variety of locally processed food products. In the food-processing sector, firms supply ingredients for culinary services. In the ICT sector, firms supply office equipment and supplies. The different sectors from which the local firms come demonstrate the extent to which South African firms are embedded in the Botswanan and Kenyan markets.

Table 8: Linkages formed by South African firms in Botswana and Kenya

\begin{tabular}{|c|c|c|c|c|c|c|c|c|c|c|c|}
\hline \multirow{4}{*}{ Types of linkage } & \multicolumn{4}{|c|}{ Botswana } & \multicolumn{6}{|c|}{ Kenya } & \\
\hline & \multicolumn{2}{|c|}{ SA1 } & \multicolumn{2}{|c|}{$\mathrm{SA} 2$} & \multicolumn{2}{|c|}{ SA3 } & \multicolumn{2}{|c|}{ SA4 } & \multicolumn{2}{|c|}{ SA5 } & \\
\hline & \multicolumn{2}{|c|}{ Retail } & \multicolumn{2}{|c|}{$\begin{array}{c}\text { Food- } \\
\text { processing }\end{array}$} & \multicolumn{2}{|c|}{$\mathrm{ICT}$} & \multicolumn{2}{|c|}{ ICT } & \multicolumn{2}{|c|}{ Retail } & \\
\hline & Yes & No & Yes & No & Yes & No & Yes & No & Yes & No & Totals \\
\hline \multicolumn{12}{|l|}{ Supply } \\
\hline Local suppliers & $x$ & - & $x$ & - & $x$ & - & $x$ & - & $x$ & - & 5 \\
\hline $\begin{array}{l}\text { Foreign suppliers } \\
\text { in host country }\end{array}$ & $x$ & - & $x$ & - & - & - & $x$ & - & - & - & 3 \\
\hline \multicolumn{12}{|l|}{ Employees } \\
\hline Local employees & $x$ & - & $x$ & - & $x$ & - & $x$ & - & $x$ & - & 5 \\
\hline $\begin{array}{l}\text { Foreign employees } \\
\text { in host country }\end{array}$ & - & - & - & - & - & - & - & - & $x$ & & 1 \\
\hline \multicolumn{12}{|l|}{ Joint venture } \\
\hline Local partners & - & - & - & - & - & - & $x$ & - & - & - & 1 \\
\hline $\begin{array}{l}\text { Foreign partners } \\
\text { in host country }\end{array}$ & $x$ & - & $x$ & - & - & - & - & - & $x$ & - & 3 \\
\hline \multicolumn{12}{|l|}{ Service } \\
\hline Local providers & $x$ & - & - & - & $x$ & - & $x$ & - & $x$ & - & 4 \\
\hline $\begin{array}{l}\text { Foreign providers in } \\
\text { host country }\end{array}$ & $x$ & - & $x$ & - & $x$ & - & $x$ & - & - & - & 4 \\
\hline \multicolumn{12}{|l|}{ Institutional } \\
\hline Local institutions & - & - & - & - & - & - & $x$ & - & - & - & 1 \\
\hline $\begin{array}{l}\text { Foreign institutions } \\
\text { in host country }\end{array}$ & - & - & - & - & - & - & $x$ & - & $x$ & - & 2 \\
\hline Total & 6 & & 5 & & 4 & & 8 & & 6 & & 29 \\
\hline
\end{tabular}

Source: authors' compilation.

Employee linkages are mainly forged with workers from the host country. Employee linkages with South African workers also exist. Two reasons explain the presence of both South African workers and host country employees. First, the large presence of local employees demonstrates the efficiency-seeking nature of South African firms in addition to their market-seeking intentions. In other words, it may be costly to employ South African workers, as this might require relocations from South Africa, higher salaries, and other associated costs. Second, most firms have been operating for at least six years in Botswana and Kenya, and are therefore sufficiently familiar with the business environment to opt for local employees. In the case of SA5, which is only three years old, it makes sense to employ South African workers who will learn about the business environment in order for the firm manage and operate in a new market in Kenya. 
The South African firms have the same number of service linkages for local and foreign providers in the host country. They are mainly found in the ICT sector, and they involve distribution services, fibre installation and support, and marketing services. These services are purchased by South African firms in order to sustain their operations in the host countries.

South African investments are mainly joint ventures in the host country, according to our findings. The nature of joint ventures follows two main patterns. Joint ventures demonstrate partnerships between local firms and South African institutions operating in the host country. Institutional linkages are also forged with local firms and South African institutions operating in the host country. In summary, the linkages forged by South African firms in host countries are wide and extend to firms in different sectors in the host countries.

\subsection{Characteristics of local firms}

In terms of age, the youngest local firm was about two years old, while the oldest was 50. Firm sizes as reflected in numbers of employees reveal a blend of micro, small, medium, and large enterprises (Table 9). Large enterprises have as many as 2,000 employees, while micro enterprises have as few as four. The remaining local firms can be categorized as small and medium-sized enterprises. In terms of sector, local firms are engaged in retail, ICT, and food-processing.

Table 9: Characteristics of local firms

\begin{tabular}{|c|c|c|c|c|c|}
\hline $\begin{array}{l}\text { Data set: } \\
\text { local } \\
\text { firm (LF) }\end{array}$ & Nationality & $\begin{array}{l}\text { Length } \\
\text { of operation } \\
\text { (years) }\end{array}$ & $\begin{array}{l}\text { No. of } \\
\text { employees }\end{array}$ & Product/service & Client \\
\hline LF1 & Botswana & 2 & 18 & Warehouse interior design & SA1 \\
\hline LF2 & Botswana & 15 & 297 & Retail - food & SA2 \\
\hline LF3 & Kenya & 23 & 80 & Equipment and infrastructure & SA3 \\
\hline LF4 & Kenya & 17 & 50 & Equipment distribution & SA3 \\
\hline LF5 & Kenya & 14 & 2000 & Internet service supplies & SA3 \\
\hline LF6 & Kenya & 22 & 30 & IT service provision & SA3 \\
\hline LF7 & Kenya & 24 & 20 & IT service provision & SA3 \\
\hline LF8 & Kenya & $>20$ & 48 & Provision of office supplies & SA3 \\
\hline LF9 & Kenya & 18 & 26 & Provision of equipment & SA3 \\
\hline LF10 & Kenya & 33 & 350 & Processed food & SA5 \\
\hline LF11 & Kenya & 35 & 150 & Home and décor appliances & SA5 \\
\hline LF12 & Kenya & 48 & 2000 & Processed food & SA5 \\
\hline LF13 & Kenya & 50 & 2000 & Processed food & SA5 \\
\hline LF14 & Kenya & 20 & 450 & Processed food & SA5 \\
\hline LF15 & Kenya & 25 & 700 & Dairy products & SA5 \\
\hline LF16 & Kenya & 18 & 28 & Electrical appliances & SA5 \\
\hline LF17 & Kenya & 10 & 342 & Fibre installation, support, and reselling & SA4 \\
\hline LF18 & Kenya & 4 & 4 & Fibre installation and support & SA4 \\
\hline LF19 & Kenya & 6 & 47 & Marketing services & SA4 \\
\hline LF20 & Kenya & 2 & 11 & ICT product reselling & SA4 \\
\hline LF21 & Kenya & 12 & 20 & Telecoms contracting & SA4 \\
\hline
\end{tabular}

Source: authors' compilation. 


\subsection{Linkage and spillovers}

Due to the challenges we faced in interviewing local employees in South African firms, we focus here on spillover linkages as narrated by local firms. In terms of the types of spillover, they are generated by supply and service linkages (shown in Table 10). Spillover effects of these linkages are manifested in training, finance, intangible inputs, and advice and recommendations. In terms of the types of linkage, however, spillovers are generated by service linkage. Spillover effects are manifested in training, and advice and recommendations. Sector-wise, there are more visible spillover effects in the ICT sector. They are manifested in training, finance, intangible inputs, and advice and recommendations.

Table 10: Linkages and spillovers

\begin{tabular}{|c|c|c|c|c|c|c|}
\hline \multirow[t]{2}{*}{ Spillovers } & \multicolumn{6}{|c|}{ Type of linkage } \\
\hline & Supply & Employee & $\begin{array}{c}\text { Joint } \\
\text { venture }\end{array}$ & Services & Institutional & Total \\
\hline $\begin{array}{l}\text { Training } \\
N=21\end{array}$ & $1(\mathrm{ICT})$ & - & - & $3(\mathrm{ICT})$ & - & 4 \\
\hline $\begin{array}{l}\text { Financial support } \\
N=21\end{array}$ & 1 (ICT) & - & - & - & - & 1 \\
\hline \multicolumn{7}{|l|}{$\begin{array}{l}\text { Inputs } \\
N=21\end{array}$} \\
\hline Tangible & - & - & - & - & - & - \\
\hline Intangible & 2 (Retail) & - & - & - & - & 2 \\
\hline $\begin{array}{l}\text { Advice and } \\
\text { recommendations } \\
\mathrm{N}=21\end{array}$ & $3(\mathrm{ICT})$ & - & - & $6(\mathrm{ICT})$ & - & 9 \\
\hline $\begin{array}{l}\text { No support } \\
N=21\end{array}$ & $\begin{array}{l}7 \text { (Food- } \\
\text { processing, } \\
\text { Retail) }\end{array}$ & - & - & $2(\mathrm{ICT})$ & - & 9 \\
\hline Total & 14 & & & 11 & & 25 \\
\hline
\end{tabular}

Note: Totals figures comprise the number of responses. Some respondents indicated that they received training as well as advice and recommendations.

Source: authors' compilation.

Concerning training, one local firm in an interview revealed the following;

Our company is still young and venture profit is low, as the company has a relatively large operational cost. We have not yet broken even with the initial capital investments. But new product development is crucial for our serviceoriented firm. We benefit from trainings organized by SA4. There is technology transfer, which introduces us to new methods and products. (Data set LF20)

LF20 also receives further training from a US-based company to improve the quality of its services. Another local firm described the extent to which South African firms supported its business operations as follows:

We receive reviews from SA4, and have also synchronized our systems for the purposes of online reporting. These companies have access to market trends and can therefore target specific trends, then contract us to work for them. So we also benefit from their research, such as the current fibre and network installation in gated communities and areas across the country. (Data set LF17)

In another instance, a local firm emphasized: 
We organize collaborative trainings as service partners. The advice we get from our partner helps us grow together, as we are at par in terms of supply and quality of demand. (Data set LF7)

One local firm said:

Apart from advice and recommendations, SA4 also issues us with service letters to boost our chances of attaining other contracts. (Data set LF18)

The local firms that received no support from South African firms were established firms that had been in business for a long time. For instance, local firms LF12, LF13, and LF14 had been operating for 20 years or more before engaging in business with the relatively young SA5. That being the case, SA5 could offer little or no support besides its transaction-specific interactions.

The extent to which local firms improved their business operations after forging linkages with South African firms left much to be desired. In fact, responses from local firms reflected neither major improvements nor declines in their operations. When asked to assess any changes in its business two years before and after its linkage with a South African firm, one local firm responded:

The company has been in operation for a long time and deals in the same products as their competitors offer. Therefore, the relationship with SA3 has not changed us much, as it is business, just like other companies which are even bigger than SA3. (Data set LF3)

Another local firm placed its linkage with the South African firm in the context of other competitors, revealing little spillover from the South African firm. This local firm emphasized:

We may as well say that we have probably changed a bit because SA4 is not the only big company we have dealt with. We have worked for other multinational ICT firms before, so the changes are from all these big firms. They all have a little positive influence that helps us to grow. (Data set LF17)

Similarly, another local firm stated that there had been positive developments with payments, due to improvements in business operations:

We have been doing business with other multinational ICT firms, so the business with SA4 is just one of the big clients, just like the rest. Doing business with these firms has been made better by improvements and standards in the volatile markets, such as setting payment limits. These firms now pay up within 60 days, rather than the previous uncertain periods, where they would take even 90 days to pay up. (Data set LF21)

Nevertheless, LF21 expressed frustration that foreign firms such as SA4 introduced products that were not well suited for the domestic market, making them difficult to sell.

\subsection{Support from other entities}

Our research further investigated whether local firms received any support from entities other than South African firms. About 48 per cent of the firms interviewed confirmed that they received no support from other entities. For the remaining 52 per cent, the government, business associations, and banks provided varying support. Local firms confirmed that financial support was the largest intervention they received (Table 11). The interviewed firms reiterated that banks also offered 
financial advice and seminars where a range of topics were discussed. These forums aided their service and knowledge in the field.

Table 11: Support from other entities

\begin{tabular}{|c|c|}
\hline Support (N=21) & No. \\
\hline Training & - \\
\hline Financial support & 6 \\
\hline \multicolumn{2}{|l|}{ Inputs } \\
\hline Tangible & 1 \\
\hline Intangible & 2 \\
\hline Advice and recommendations & 2 \\
\hline No support & 10 \\
\hline Total & 21 \\
\hline
\end{tabular}

Source: authors' compilation.

For intangible inputs, one local firm (LF10) reported that the Kenya Bureau of Standards provided quality checks and certification in order to meet the standard requirements of South African firms and other firms in general. International Organization for Standardization certificates appeared to be the common standard, followed by Hazard Analysis and Critical Control Points, and halal certification. Nevertheless, our research revealed that acquiring certification to ease business transactions and expand market scope was still a challenge for local firms. The local firms we interviewed complained that certification was a demanding exercise, particularly for small firms. Indeed, the certified local firms, which comprised eight of the 19, represented the larger and more established firms. Moreover, local firms perceived that certification was no guarantee of business. For others, certification was not a requirement in their line of business.

Another local firm, LF11, emphasized the indirect role played by the government in encouraging the consumption of locally produced goods as a way to control the entry of illegal and cheap imports into the Kenyan market. This is being promoted by the government's 'Buy Kenya, Build Kenya' initiative. With regard to tangible inputs, LF12 lauded the efforts of private-sector players such as Safaricom's DigiFarm, which supports farmers with a steady supply of soya beans through loans. This ensures a steady supply of raw materials for firms who are involved in food-processing.

Other firms pointed to the role played by business associations. For instance, local firm LF13 stated that local firms that belong to business associations are able to speak with one voice to promote their interests:

We do not receive any additional support from SA5. We receive support from business associations of which we are members. For instance, the Kenyan Association of Manufacturers lobbies the government on our behalf. (Data set LF13)

Similarly, another firm reported:

There is no further support from SA5, but we receive support from business associations. Business associations agitate for the local content-stocking policy. The association has been agitating for the enforcement and adoption of a policy that requires supermarkets to stock 70 per cent locally sourced products on their shelves. (Data set LF14) 
This paper has sought to investigate the linkages and spillovers of South African FDI in Botswana and Kenya. The South African firms interviewed for this study were in the food-processing, retail, and ICT sectors. Linkages forged in these sectors include supply, employee, joint venture, service, and institutional nexuses. The presence of spillovers is largely low in Botswana and Kenya. In cases where they exist, our findings point to the fact that younger local firms tend to benefit from South African firms in terms of technology transfer and training opportunities. Alongside South African FDI, other foreign multinationals with linkages to local firms also operate in host countries. Therefore, it is difficult to attribute any improvements in the capability of local firms to South African FDI alone. In parallel with the minimal South African FDI support, our findings also reveal both public- and private-sector support for local firms. This includes government policies on local content and interventions on standardization, the private sector's quest to provide soft loans, business associations' lobbying on behalf of their members, and banks' support to provide monetary and pecuniary benefits.

The findings also have policy implications for the promotion of entrepreneurship. It was found that South African FDI directly or indirectly supports young firms through technology transfer and training opportunities. While policy initiatives to attract FDI in general are laudable, innovative policies are still needed to attract entrepreneurship-promoting South African FDI in the subregion. This can be done by engaging start-ups and South African firms through the cohort approach. In the context of this research, South African firms and relevant host country partners could place local firms in their formative stages into a group. Thereafter, South African firms could provide results-oriented support in best supplier or service provision practices, while allowing local interfirm engagement. This would have a strong tendency to stimulate entrepreneurial drive among young people, with far-reaching consequences for innovation in host countries.

Our findings provide further interesting evidence for policymaking. On the one hand, the spillovers created are highly dependent on the type of linkage being forged. Thus, the type of linkage is a crucial determinant of the success of the linkage. On the other hand, the type of sector highly influences the spillover to be generated. Similarly, the type of sector to which FDI is attracted plays a critical role in determining whether spillovers are generated. Host country policies should therefore be directed towards attracting investments with far-reaching implications for the type of sector attracted and the type of linkage created. Careful examination should be conducted to earmark FDI in different contexts of the SADC and other subregions. For instance, Kenya has a strong ICT sector, with booming start-ups in this field. Government policies could target FDI that stimulates upstream and downstream industries, for employment and consequent tax revenues to be collected by host country governments.

Similarly, the findings give hints for policy directives that could attract what we term 'doubleedged' FDI in host countries, i.e. FDI that can forge multiple linkages in host countries. In our research, South African firms in the ICT sector demonstrated linkages in supply and service provision. Thus, there is a tendency for FDI in ICT to extend to different types of linkage in the host country. Policy directives should therefore vigorously aim to attract FDI, not necessarily in the ICT sector, but in any sector that has immense potential to forge multiple linkages with the host country. This can be promoted by attracting FDI into dynamic clusters in host countries. Clusters offer benefits such as the available supply of inputs and specialized services in close proximity. We contend that policies that attract double-edged FDI into clusters will have a higher chance of generating desirable spillovers that will improve local firms' capability. 
Although the findings report that advice and recommendations are the most generated spillover, we contend that this cannot catalyse local firms' capability-building in a compelling way. Advice and recommendations are subjective and may be applied at the discretion of the local firm, given that they are not obligatory. Targeted trainings are concrete spillovers that can be effectively promoted to effect desired changes in the capabilities and quality output of local firms. This can be encouraged by attracting South African firms that are already embedded in global or international value chains. These firms have acquired valuable knowledge, which local firms can tap by virtue of existing linkages. The knowledge can be transferred through targeted trainings on the standards, design, and quality preferred by South African firms. Given this, FDI embedded in global or international value chains has a higher tendency to drive and improve the productivity and quality level of local firms.

South African FDI is by no means of small value to host countries, and it should therefore be given the support it needs to enhance host countries' employment-generating efforts. At the same time, South African FDI should not entail enclave behaviour that is detrimental to host countries' business landscapes. Policies that promote joint ventures with host country firms offer a good approach to mitigate the crowding out of local firms while enhancing learning opportunities and demonstration effects.

The findings of our research should be interpreted with caution. The data is insufficiently large to warrant generalization. In the case of Botswana, we found that while there were linkages formed by South African firms, such linkages were purely based on transactions. Thus our findings are not conclusive regarding the linkage and spillover effects of South African FDI in Botswana, nor in Kenya. There must be large-scale investigation in future to reflect the impact of South African FDI in the subregion, and in Africa at large.

\section{References}

Adeyele, I., F. Ngwu, N. Iheanachor, E. Esho, C. Oji, T. Onaji-Benson, and C. Ogbechi (2018). 'Banking on Africa: Can Emerging Pan-African Banks Outcompete Their Global Rivals?' In I. Adeleye and M. Esposito (eds), Africa's Competitiveness in the Global Economy. Cham: Palgrave Macmillan.

Adu-Gyamfi, R. (2017). 'Export Processing Zones and the Host Economy: Analysing Firm Linkage and Local Supplier Development in Ghana'. PhD thesis. Leipzig: Leipzig University.

African Development Bank (2019). African Economic Outlook. Abidjan: African Development Bank.

Ahouakan, E.W.V., and M. Diene (2017). 'Does School Quality Matter? Primary Schools' Characteristics and Child Labour Intensity in Senegal'. Journal of African Development, 19(1): 113-31.

Altenburg, T. (2000). 'Linkages and Spillovers Between Transnational Corporations and Small and Medium Sized Enterprises in Developing Countries: Opportunities and Policies'. Reports and Working Papers 5/2000. Berlin: German Development Institute.

Biernacki, P., and D. Waldorf (1981). 'Snowball Sampling: Problems and Techniques of Chain Referral Sampling'. Sociological Methods and Research, 10(2): 141-63.

Blomström, M., and A. Kokko (1998). 'Multinational Corporations and Spillovers'. Journal of Economic Surveys, 12(3): 247-77. DOI:10.1111/1467-6419.00056.

Boamah, N.A. (2017). 'The Relevance of Global Sector Influence in African Sector Portfolios'. African Journal of Economic and Management Studies, 8(2): 205-20. 
Chen, T.J., H. Chen, and Y.H. Ku (2004). 'Foreign Direct Investment and Local Linkages'. Journal of International Business Studies, 35(4): 320-33.

Cisse, F. (2017). 'Do Firms Learn by Exporting or Learn to Export? Evidence from Senegalese Manufacturing Firms'. Journal of African Development, 19(1): 133-60.

Crone, M., and S. Roper (2001). 'Local Learning from Multinational Plants: Knowledge Transfers in the Supply Chain'. Regional Studies, 35(6): 535-48.

Cuero Acosta, Y.A., R. Adu-Gyamfi, M.N.U. Nabi, and U. Dornberger (2017). 'Analysing the Role of Framework Conditions Influencing International Entrepreneurial Opportunity Identification Process'. Entrepreneurial Business and Economics Review, 5(3): 9-29. DOI:10.15678/EBER.2017.050301.

Cui, L., K.E. Meyer, and H.W. Hu (2014). 'What Drives Firms' Intent to Seek Strategic Assets by Foreign Direct Investment? A Study of Emerging Economy Firms'. Journal of World Business, 49(4): 488-501. DOI:10.1016/j.jwb.2013.12.003.

Dunne, J.P., and N. Masiyandima (2017). 'Bilateral FDI from South Africa and Income Convergence in SADC'. African Development Review, 29(3): 403-15.

Dunning, J.H. (1993). Multinational Enterprise and the Global Economy. Wokingham: Addison-Wesley.

Elu, J.U., and G.N. Price (2017). 'Science Labor Supply in Sub-Saharan Africa: Is There a Gender Disparity in Preferences?' African Development Review, 29(3): 367-75.

Fanta, A.B., and D. Makina (2017). 'Equity, Bonds, Institutional Debt and Economic Growth: Evidence from South Africa'. South African Journal of Economics, 85(1): 86-97.

fDi Intelligence (2017). The fDi Report 2017: Global Greenfield Investment Trends. London: Financial Times.

fDi Intelligence (2018). The fDi Report 2018: Global Greenfield Investment Trends. London: Financial Times.

Fedderke, J.W., and D.K. Mengisteab (2017). 'Estimating South Africa's Output Gap and Potential Growth Rate'. South African Journal of Economics, 85(2): 161-77.

Gereffi, G. (1999). 'International Trade and Industrial Upgrading in the Apparel Commodity Chain'. Journal of International Economics, 48: 37-70.

Gereffi, G., and K. Fernandez-Stark (2016). Global Value Chain Analysis: A Primer. 2nd ed. Durham, NC: Duke University, Center on Globalization, Governance, and Competitiveness.

Giroud, A., and J. Scott-Kennel (2009). 'MNE Linkages in International Business: A Framework for Analysis'. International Business Review, 18(6): 555-66. DOI:10.1016/j.ibusrev.2009.07.004.

Henderson, J., P. Dicken, M. Hess, N. Coe, and H.W.C. Yeung (2002). 'Global Production Networks and the Analysis of Economic Development'. Review of International Political Economy, 9(3): 436-64.

Hymer, S. (1976). The International Operations of National Firms: A Study of Direct Foreign Investment. Cambridge, MA: MIT Press.

Irungu, G. (2010). 'New Wave of S. African Investments Hits Kenya'. Business Daily, 9 November. Available at: www.businessdailyafrica.com/markets/New-wave-of-S--African-investmentshits-Kenya/539552-1050268-b10bjkz/index.html (accessed 28 February 2019).

ITC (2017). 'SME Guide to Value Chains'. Geneva: ITC. 
Ivarsson, I., and C.G. Alvstam (2005). 'Technology Transfer from TNCs to Local Suppliers in Developing Countries: A Study of AB Volvo's Truck and Bus Plants in Brazil, China, India, and Mexico'. World Development, 33(8): 1325-44.

Konfidants (2017). 'African Globalizers Report: African Firms Taking the World Stage'. Accra: Konfidants. Available at: www.konfidants.com/wpcontent/uploads/2018/01/African_Globalizers_Report_2017_Konfidants.pdf (accessed 3 March 2019).

Kreuser, C.F., and C. Newman (2018). 'Total Factor Productivity in South African Manufacturing Firms'. South African Journal of Economics, 86(1): 40-78.

Kuada, J. (2005). 'Linkages and Upgrading in Ghana's Export Processing Zones'. In J. Kuada (ed.), Internationalization and Enterprise Development in Ghana. London: Adonis and Abbey.

Labour Research Service (2017). 'Closing the Remuneration Gap: South African Multinational Corporations in Africa - Trends in 2016'. Johannesburg and Cape Town: Friedrich Ebert Stiftung and Labour Research Service. Available at lrs.org.za/media/2018/3/b689d7f7-56a742f3-b85e-147d4919e436-1520519873183.pdf (accessed 30 May 2019).

Labour Research Service (2019). 'Labour Research Service: Multinational Corporations Database'. Available at: database.lrs.org.za/mnc/ (accessed 6 March 2019).

Liu, S., and R. Vince (1999). 'The Cultural Context of Learning in International Joint Ventures'. Journal of Management Development, 18(8): 666-75.

Maryam, K., and Z. Jehan (2018). 'Total Factor Productivity Convergence in Developing Countries: Role of 'Technology Diffusion'. South African Journal of Economics, 86(2): 247-62.

McCormick, D. (1999). 'African Enterprise Clusters and Industrialization: Theory and Reality'. World Development, 27(9): 1531-51.

Meniago, C., and S.A. Asongu (2019). 'Harnessing FDI Spillovers on TFP and Economic Growth in Sub-Saharan Africa: The Relevance of Value Chains Across Economic Sectors'. Working Paper. Yaoundé: African Governance and Development Institute.

Meyer, K.E. (2015). 'What Is “Strategic Asset Seeking FDI”?' Multinational Business Review, 23(1): $57-66$.

Miozzo, M., and D. Grimshaw (2008). 'Service Multinationals and Forward Linkages with Client Firms: The Case of IT Outsourcing in Argentina and Brazil'. International Business Review, 17(1): $8-27$.

Muchira, N. (2017). 'Move Over, East African Firms, the South Africans Are Here'. East African and Business Daily, 23 May. Available at: www.theeastafrican.co.ke/business/South-Africancompanies-in-East-Africa/2560-3938184-uw709m/index.html (accessed 12 February 2019).

Nandonde, F.A. (2016). 'Integrating of Local Food Suppliers in Modern Food Retail in Africa'. PhD thesis. Aalborg: Aalborg University.

Newman, C., J. Page, J. Rand, A. Shimeles, M. Söderbom, and F. Tarp (2016). 'Made in Africa: Learning to Compete in Industry'. Washington, DC: Brookings Institution.

Porter, M. (1990). The Competitive Advantage of Nations. New York: Free Press.

Prashantham, S. (2019). 'The Two Ways for Startups and Corporations to Partner'. Harvard Business Review, 30 January. Available at: hbr.org/2019/01/the-two-ways-for-startups-andcorporations-to-partner (accessed 14 March 2019).

Ramasamy, B., M. Yeung, and S. Laforet (2012). 'China's Outward Foreign Direct Investment: Location Choice and Firm Ownership'. Journal of World Business, 47: 17-25. 
Reuber, G.L., with H. Crookell, M. Emerson, and G. Gallais-Hamonno (1973). Private Foreign Investment in Development. Oxford: Clarendon Press.

Rugraff, E., and M. Hansen (2011). 'Multinational Corporations and Local Firms in Emerging Economies: An Introduction'. In E. Rugraff and M. Hansen (eds), Multinational Corporations and Local Firms in Emerging Economies. Amsterdam: Amsterdam University Press.

Santangelo, G.D. (2009). 'MNCs and Linkages Creation: Evidence from a Peripheral Area'. Journal of World Business, 44(2): 192-205. DOI:10.1016/j.jwb.2008.05.009.

Schmitz, H. (1992). 'On the Clustering of Small Firms'. IDS Bulletin, 23(3): 64-69.

Scott-Kennel, J., and P. Enderwick (2004). 'Inter-Firm Alliance and Network Relationships and the Eclectic Paradigm of International Production: An Exploratory Analysis of QuasiInternalisation at the Subsidiary Level'. International Business Review, 13(4): 425-45.

Scott-Kennel, J., and P. Enderwick (2005). 'Economic Upgrading and Foreign Direct Investment: Exploring the Black Box of the IDP'. Transnational Corporations, 14(1): 105-37.

Si, S.X., and G.D. Bruton (2005). 'Knowledge Acquisition, Cost Savings, and Strategic Positioning: Effects on Sino-American IJV Performance'. Journal of Business Research, 58(11): 1465-73.

Smarzynska Javorcik, B. (2004). 'Does Foreign Direct Investment Increase the Productivity of Domestic Firms? In Search of Spillovers Through Backward Linkages'. American Economic Review, 94(3): 605-27. DOI:10.1257/0002828041464605.

Ssozi, J., and S.A. Asongu (2016a). 'The Comparative Economics of Catch-up in Output per Worker, Total Factor Productivity and Technological Gain in Sub-Saharan Africa'. African Development Review, 28(2): 215-28.

Ssozi, J., and S.A. Asongu (2016b). 'The Effects of Remittances on Output per Worker in SubSaharan Africa: A Production Function Approach'. South African Journal of Economics, 84(3): 400-21.

Steckler, A., K.R. McLeroy, R.M. Goodman, S.T. Bird, and L. McCormick (1992). 'Toward Integrating Qualitative and Quantitative Methods: An Introduction'. Health Education Quarterly, 19: 1-8.

Sutton, J. (2012). Competing in Capabilities: The Globalization Process. Oxford: Oxford University Press.

Tamara, P. (2018). 'Regional Value Chains: Exploring Linkages and Opportunities in the AgroProcessing Sector Across Five SADC Countries'. Working Paper 4/2018. Johannesburg: University of Johannesburg and CCRED.

UNCTAD (2018). World Investment Report 2018: Investment and New Industrial Policies. Geneva: UNCTAD. Available at: unctad.org/en/PublicationsLibrary/wir2018_en.pdf (accessed 25 February 2019).

Vernon, R. (1966). 'International Trade and International Investment in the Product Cycle'. Quarterly Journal of Economics, 80(2): 190-207. 